\title{
Peningkatan Prestasi Belajar Mata Pelajaran Bahasa Arab Melalui Metode Jigsaw Learning Di Kelas X MA Al-Khairaat Buntulia Tahun Pelajaran 2019/2020
}

\author{
Sahara Abdulah Bamu \\ Guru MA Al-Khairaat Buntulia \\ sahara@gmail.com \\ Received: 04 March 2021; Revised: 26 April 2021; Accepted: 28 July 2021 \\ DOI: http://dx.doi.org/10.37905/aksara.7.3.1201-1206.2021
}

\begin{abstract}
Abstrak
Penelitian ini merupakan upaya untuk peningkatan prestasi belajar dengan menerapkan metode jigsaw learning pada siswa kelas X MA Al-Khairaat Buntulia. Dengan menerapkan metode jigsaw learning diharapkan dapat meningkatkan kualitas pembelajaran sehingga terjadi peningkatan prestasi belajar. Desain penelitian ini adalah penelitian tindakan dengan subyek siswa kelas X MA Al-Khairaat Buntulia. Pengumpulan data dalam penelitian ini dilakukan dengan cara melakukan observasi dan tes tertulis setiap individu dan kelompok pada akhir pelajaran. Data yang diperoleh dari tiap-tiap siklus dianalisis dengan deskriptif kualitatif dan kuantitatif. Hasil penelitian menunjukan bahwa keterlibatan siswa meningkat yang berdampak pada prestasi belajar siswa mengalami peningkatan setelah dilaksanakan pembelajaran dengan menerapkan metode jigsaw learning, dengan hasil sebagai berikut: pada siklus I rata-rata nilai kelas 6,21 meningkat menjadi 6,72 pada siklus II dan lebih meningkat lagi pada siklus III menjadi 8,24
\end{abstract}

Kata Kunci : Prestasi belajar, metode Jigsaw Learning

\section{PENDAHULUAN}

Pendidikan adalah suatu hal yang penting dan mutlak bagi manusia, melalui pendidikan manusia mengembangkan kemampuan dan kepribadiannya. Bentuk kongkret dari pendidikan yang dilakukan manusia tersebut tampak dalam aktifitas pembelajaran sebagaimana Sudjana (1989:23) mengatakan bahwa proses pembelajaran merupakan suatu kegiatan untuk mencapai tujuan pendidikan yang telah ditetapkan.

Pembelajaraan merupakan suatu kegiatan yang melibatkan seseorang dalam upaya memperoleh pengetahuan, ketrampilan dan nilai-nilai positif dengan memanfaatkan berbagai sumber untuk belajar. Dalam kegiatan pembelajaran ini menunjuk pada kegiatan yang didalamnya terdapat integrasi dan interaksi komponenkomponen pembelajaran yang dapat dikategorikan menjadi tiga hal pokok yaitu guru, materi pelajaran dan siswa. Interaksi antara tiga komponen utama melibatkan sarana dan prasana seperti metode pembelajaran, media pembelajaran, setting kelas sehingga tercipta situasi pembelajaran yang memungkinkan tercapainya tujuan yang telah direncanakan. 
Guru seyogyanya mampu menentukan metode pembelajaran yang dipandang dapat membelajarkan siswa secara aktif melalui proses pembelajaran yang dilaksanakan agar tujuan pembelajaran dapat tercapai secara efektif dan hasil belajarpun dapat lebih ditingkatkan. Hal terpenting dalam kegiatan pembelajaran adalah terjadinya proses belajar (learning proses) pada diri siswa.

Proses pembelajaran yang dilakukan oleh sebagian besar guru masih ada yang cenderung pada pencapaian target materi kurikulum, lebih mementingkan pada penghafalan konsep bukan pada pemahaman. Hal ini dapat dilihat dari kegiatan pembelajaran di dalam kelas yang selalu didominasi oleh guru. Dalam penyampaian materi, biasanya guru menggunakan metode yang monoton seperti metode ceramah, dimana siswa hanya duduk, mencatat, dan mendengarkan apa yang disampaikannya dan sedikit peluang bagi siswa untuk bertanya, sehingga siswa merasa jenuh dalam mengikuti proses pembelajaran. Dengan demikian, suasana pembelajaran menjadi tidak kondusif karena siswa menjadi pasif.

Kondisi seperti itu terjadi pula pada kegiatan pembelajaran mata pelajaran Bahasa Arab di kelas X MA Al-Khairaat Buntulia. Kondisi awal kegiatan belajar mengajar di kelas tersebut untuk mata pelajaran Bahasa Arab menunjukkan hasil belajar siswa rendah dan belum mencapai kriteria ketuntasan belajar (KKM), ini dapat dilihat dari 33 siswa, 17 orang siswa atau $50 \%$ siswa kelas X nilainya kurang dari 65 sebagai batas KKM. Hasil refleksi diri menunjukkan bahwa rendahnya prestasi belajar tersebut diantaranya sikap pasif siswa dalam proses pembelajaran, proses pembelajaran yang kurang bervariasi dan monoton, dominasi guru masih sangat besar sehingga siswa kurang mandiri yang berpengaruh terhadap prestasi belajar. Salah satu alternatif yang dapat dilakukan oleh guru untuk lebih mengaktifkan belajar siswa di kelas yaitu dengan menggunakan metode Jigsaw Learning

\section{METODE PENELITIAN \\ Waktu dan Tempat Penelitian}

Penelitian dilaksanakan di Kelas X MA Al-Khairaat Buntulia dengan jumlah siswa sebanyak 33 siswa pada semester II tahun pelajaran 2019/2020. Penelitian dilaksanakan tanggal 10 April 2020 untuk siklus I, dan pada tanggal 24 April 2020 untuk siklus II dan dilanjutkan siklus III pada tanggal 1 Mei 2020.

\section{Rancangan Penelitian}

Rancangan penelitian yang ditetapkan berupa penelitian tindakan kelas. Prosedur dan langkah-langkah penelitian mengikuti prinsip-prinsip dasar yang berlaku dalam penelitian tindakan. Menurut Suharsimi Arikunto (2007:2) Penelitian Tindakan Kelas dalam bahasa Inggris adalah Classroom Action Research (CAR) yang artinya sebuah kegiatan penelitian yang dilakukan di kelas. Secara terperinci tahapan-tahapan dalam rancangan penelitian tindakan kelas adalah sebagai berikut:

a. Menyusun Rancangan Tidakan (planning)

Tahapan ini beripa menyusun rancangan tindakan yang menjelaskan tentang apa, mengapa, kapan, dimana, oleh siapa dan bagaimana tindakan tersebut akan dilakukan.

b. Tahap Pelaksanaan (Acting)

Pada tahap ini, rancangan strategi dan skenario penerapan pembelajaran akan diterapkan. Rancangan tersebut tentu saja sebelumnya telah "dilatihkan" kepada 
pelaksana tindakan (guru) untuk dapat diterapkan didalam kelas sesuai skenarionya. Skenario dari tindakan harus dilaksanakan dengan baik dan tampak wajar.

c. Tahap Pemantauan (observing)

Tahap ini berjalan bersamaan saat pelaksanaan. Pemantauan terhadap siswa dilakukan dengan mencatat semua hal yang diperlukan berupa data kuantitatif yaitu hasil tes, diskusi kelompok. Data kualitatif yaitu gambaran keaktifan siswa.

d. Refleksi (Reflecting)

Tahap ini dimaksudkan untuk mengkaji secara menyeluruh tindakan yang telah dilakukan, berdasarkan data yang telah terkumpul kemudian melakukan evaluasi guna menyempurnakan tindakan berikutnya. Refleksi sangat tepat dilakukan ketika guru pelaksana telah selesai melakukan tindakan (Arikunto, Suhardjono 2008 :19).

\section{Pengumpulan Data} lain:

Teknik yang digunakan untuk mengumpulkan data dalam penelitian ini antara

a. Test

Tes diberikan pada setiap siklus untuk mengetahui peningkatan prestasi belajar siswa.

b. Pengamatan/observasi

Dipandu dengan lembar pengamatan yang dilakukan langsung oleh peneliti untuk memperoleh data penelitian, aktifitas siswa dan data keterampilan guru selama proses pembelajaran berlangsung. Hal ini berfungsi untuk mengetahui peningkatan hasil belaja.

c. Dokumentasi

Untuk memperoleh data tentang kondisi sekolah, data siswa, data guru dan lain-lain.

\section{Analisis Data}

Analisis data yang digunakan dalam penelitian diwakili oleh momen refleksi putaran. Dari refleksi tindakan putaran pertama akan diperoleh hasil yang kemudian menjadi evaluasi pelaksanaan pembelajaran untuk peningkatan pembelajaran pada siklus berikutnya, sehingga dengan melakukan refleksi tersebut peneliti akan memiliki wawasan otentik dalam menafsirkan data. Dari putaran refleksi dalam siklus akan diberhentikan apabila telah terpenuhi tuntas nilai Kriteria Ketuntasan Minimal (KKM) untuk seluruh siswa kelas X.

\section{HASIL PENELITIAN DAN PEMBAHASAN Deskripsi Per Siklus}

Untuk mengukur keberhasilan siswa dalam mengikuti pelajaran, pada kegiatan akhir peneliti mengadakan evaluasi. Adapun hasil evaluasi tersebut dapat dijelaskan sebagai berikut:

Pada pelaksanaan pembelajaran siklus I hasil evaluasi menunjukkan peningkatan. Dari 33 siswa ada 14 siswa yang memperoleh nilai 6,50 ke atas. Rata-rata kelas 6,49. ketuntasan belajar $42,4 \%$.

Dari data tersebut dapat dilihat bahwa 33 siswa masih ada 19 siswa yang belum tuntas belajar. Hal ini disebabkan oleh beberapa kemungkinan seperti dibawah ini :

1. Peneliti dalam menggunakan metode secara monoton sehingga siswa merasa jenuh. 
2. Proses pembelajaran didominasi oleh guru sehingga siswa kurang aktif dalam proses pembelajaran.

Untuk mengatasi kelemahan-kelemahan tersebut peneliti harus memperbaiki pada kinerja siklus II. Bentuk perbaikan ditempuh dengan menerapkan metode jigsaw learning.

Setelah dilaksanakan perbaikan pembelajaran siklus II, hasil evaluasi menunjukkan peningkatan dari perbaikan pembelajaran siklus I. Peningkatan tersebut seperti berikut ini Pada pelaksanaan pembelajaran siklus I, dari 33 siswa hanya 14 siswa yang memperoleh nilai 7 keatas. Setelah dilaksanakan perbaikan pada siklus II hasil evaluasi menunjukkan peningkatan. Dari 33 siswa ada 17 siswa yang memperoleh nilai 7,0 ke atas. Rata-rata kelas yang semula 6,49 menjadi 7,0. Sedangkan ketuntasan belajar semula $42,4 \%$ menjadi $63,6 \%$.

Ketuntasan belajar mencapai $63,6 \%$ sedangkan semula $42,4 \%$, atau mengalami kenaikan 21,2\% sedangkan nilai rata-rata kelas menjadi 7,0. Pengubahan strategi yang dilakukan guru mampu meningkatkan prestasi belajar siswa. Masih ada 16 siswa yang belum tuntas belajarnya. Peneliti memberikan bimbingan khusus kepada 16 siswa tersebut.

Setelah dilaksanakan pembelajaran siklus III, hasil evaluasi menunjukkan peningkatan dari pembelajaran siklus III. Peningkatan tersebut seperti berikut ini.

Dari 33 siswa, ada 29 siswa yang berhasil mencapai ketuntasan belajar, rata-rata kelas 8,24 hasil evaluasi pada siklus III menunjukkan peningkatan. Dari 33 siswa ada 29 siswa berhasil mencapai ketuntasan belajar. Ketuntasan belajar mencapai 87,9\% sedangkan semula $67,7 \%$, atau mengalami kenaikan $20,2 \%$ sedangkan nilai rata-rata kelas menjadi 8,24 . Pengubahan strategi yang dilakukan guru mampu meningkatkan prestasi belajar siswa. Masih ada 4 siswa yang belum tuntas belajarnya.

\section{Pembahasan}

Perbaikan pembelajaran siklus I yang difokuskan pada penjelasan materi macammacam puasa menurut hukumnya dengan menggunakan metode jigsaw learning. Nilai rata-rata siswa 6,49. Hal ini menunjukkan bahwa kegiatan pembelajaran belum mencapai KKM dan pada siklus berikutnya harus diperbaiki.

Pada perbaikan pembelajaran siklus II nilai rata-rata siswa dan tingkat pencapaian ketuntasan belajar meningkat. Nilai rata-rata siswa meningkat dari 6,49 menjadi 7,0. Tingkat ketuntasan belajar meningkat dari 42,4\% menjadi 51,5\%. Peningkatan prestasi belajar siswa dapat tercapai karena guru dengan melaksanakan perbaikan pembelajaran dengan baik.

Melalui perbaikan pembelajaran Bahasa Arab yang dilaksanakan dalam siklus ini, pemahaman siswa tentang pembelajaran ketentuan-ketentuan puasa ramadlan dapat ditingkatkan. Pemahaman siswa terhadap materi pelajaran meningkat karena peneliti selaku guru melaksanakan seluruh kegiatan perbaikan yang telah direncanakan dengan sungguh-sungguh.

Pada perbaikan pembelajaran siklus III nilai rata-rata siswa dan tingkat pencapaian ketuntasan belajar meningkat. Nilai rata-rata siswa meningkat dari 7,0 menjadi 8,44. Tingkat ketuntasan belajar meningkat dari 51,5\%. menjadi 87,9\%. 
Dari 33 siswa masih ada 4 siswa yang tidak tuntas KKM. Hal ini disebabkan faktor dari diri siswa yang hiperaktif, tidak memperhatikan pembelajaran serta serimg tidak masuk dengan berbagai alasan.

Sebanyak 29 siswa tuntas KKM atau 87,9\% mencapai ketuntasan belajar, prestasi belajar siswa meningkat. Peningkatan prestasi belajar siswa dapat tercapai karena guru dengan melaksanakan perbaikan pembelajaran dengan baik.

Melalui perbaikan pembelajaran Bahasa Arab yang dilaksanakan dalam siklus ini, pemahaman siswa tentang pembelajaran khikmah puasa dapat ditingkatkan. Pemahaman siswa terhadap materi pelajaran meningkat karena peneliti selaku guru melaksanakan seluruh kegiatan perbaikan yang telah direncanakan dengan sungguh-sungguh.

\section{PENUTUP}

\section{Kesimpulan}

Dari hasil kegiatan pembelajaran dengan menerapkan metode jigsaw learning yang telah dilakukan selama tiga siklus, dapat disimpulkan bahwa Pembelajaran dengan menerapkan metode jigsaw learnng memiliki dampak positif dalam meningkatkan prestasi belajar siswa dengan nilai rata-rata 6,49 pada siklus I, menjadi 7,00 pada siklus II dan meningkat lagi menjadi 8,44 pada siklus III. Keberhasilan proses pembelajaran ditandai dengan peningkatan ketuntasan belajar siswa dalam setiap siklus, yaitu siklus I (42,4\%), siklus II (51,5\%) siklus III (87,9\%).

\section{Saran}

Dari hasil penelitian yang diperoleh dari uraian sebelumnya agar proses belajar mengajar Bahasa Arab lebih efektif dan lebih memberikan hasil yang optimal bagi siswa, maka peneliti memiliki saran sebagai berikut:

1. Guru Bahasa Arab untuk dapat secara kreatif mencobakan dan mengembangkan model pembelajaran tersendiri yang khas, sesuai dengan kondisi nyata di tempat kerja masing-masing, sehingga pada gilirannya akan muncul model-model pembelajaran versi guru yang bersangkutan, yang tentunya semakin memperkaya khazanah model pembelajaran yang telah ada.

2. Guru harus dapat menjaga dan membina keterlibatan aktif siswa dalam kegiatan pembelajaran agar daya serap anak terhadap materi yang diberikan guru menjadi lebih mantap.

3. Kepada Kepala Sekolah untuk dapat senantiasa memotivasi guru-guru di sekolahnya agar mengembangkan profesionalitasnya sebagai pendidik

\section{DAFTAR PUSTAKA}

Al-Mundziri,1994. Ringkasan Hadits Shahih Muslim. Jakarta :Pustaka Imani Arikuto, Suharsimi,2007.Penelitian Tindakan Kelas: Bumi Aksara

Penelitian Tindakan Kelas. Jakarta: Bumi Aksara

Bahri Djamarah, Syaiful.1994.Guru dan Anak Didik dalam Interaksi Edukatif. Bandung: Rineka Cipta

Hamalik,Oemar.2010. Psikologi Belajar. Bandung: PT Sinar Baru Algesindo Khairudin.2007. Kurikulum Tingkat Satun Pendidikan.Jogjakarta: Nuansa Aksara. Jamaludin, 2002.Pembelajaran yang Efektif.Jakarta; Departemen Agama RI 
Purwanto, M. Ngalim.2003. Psikologi Pendidikan, Bandung: PT Remaja Rosda Karya.

Slameto, 2001. Belajar dan Faktor-Faktor yang mempengaruhinya .Jakarta:Bumi Aksara.

S.M, Ismail.2008. Strategi Pembelajaran Agama Islam Berbasis PAIKEM. Semarang: Rasail Media Group.

Surya Brata, Sumadi,1993. Psikologi Pendidikan, Jakarta: raja grafindo persada

Sumiati,2008.Metode Pembelajaran (seri Pembelajaran Efektif) Bandung: CV Wacana Prima

Syah, Muhibin. 1999.Psikologi Belajar. Jakarta: PT Logos Wacana Ilmu 